\title{
HUBUNGAN KEWARISAN ANTAR AGAMA DALAM PERSPEKTIF ISLAM
}

\author{
Muhsin Aseri ${ }^{1}$ dan M. Zaki Mubarak ${ }^{2}$ \\ STAI Darul Ulum Kandangan \\ muhsinaseri7@gmail.com ${ }^{1}$
}

\begin{abstract}
Abstrak
Warisan dan pewarisan dalam keluarga menjadi isu yang menarik untuk selalu diulas dan dikaji, khususnya dalam kasus pewarisan bagi keluarga dengan status keyakinan yang berbeda. Tidak jarang dalam kasus di masyarakat masih berlaku pewarisan dari keluarga yang antara orangtua dan anak, maupun saudara yang dalam prakteknya ada yang saling waris mewariskan. Penelitian ini bertujuan untuk mengungkap bagaimana sebenarnya hubungan kewarisan antar agama bagi ahli waris. Penelitian yang merupakan penelitian pustaka ini bersumber bahan hukum primer, sekunder dan bahan hukum tersier dengan pendekatan konseptual dan filosofis serta menggunakan analisis deskriptif kualitatif. Penelitian ini menemukan, bahwa perbedaan agama tetap menjadi satu pengahalang kewarisan. Namun terhalangnya kedua orang tua dan kerabat mendapatkan warisan karena perbedaan agama, tidak menghalangi mereka memperoleh bagian harta peninggalan pewaris melalui jalur hukum wasiat atau wasiat wajibah. Penelitian ini berkontribusi untuk memberikan diskusi yang khusus membahas tema yang dimaksud sehingga bisa menjembatani permasalahan yang sudah terjadi di masyarakat secara umum.
\end{abstract}

Kata kunci: ahli waris, antar agama, hubungan kewarisan.

\section{PENDAHULUAN}

Salah satu aspek hukum Islam yang dijelaskan secara terinci dalam Alquran adalah tentang hukum kewarisan. Kewarisan merupakan persoalan yang menjadi perhatian serius agama Islam dan ia sangat erat kaitannya dengan harta benda dan pemindahan kepemilikannya, bahkan kewarisan merupakan salah satu sebab terpenting terjadinya pemilikan harta. Harta benda termasuk salah satu sebab di antara beberapa masalah yang menjadi kecenderungan dan kecintaan manusia sebagaimana ditegaskan Allah swt dalam surat Ali Imran ayat 14 dan al-Taubah ayat $24 .{ }^{1}$

\footnotetext{
${ }^{1}$ Muhammad Idzhar, "Hukum Kewarisan Islam (Studi Pelaksanaan Kewarisan Masyarakat Beda Budaya Kabupaten Kutai Kartanegara),” Journal of Chemical Information and Modeling 53, no. 9 (2013).
}

Al Qalam: Jurnal Ilmiah Keagamaan dan Kemasyarakatan Vol. 16, No. 2

$$
\text { Maret - April } 2022
$$


Di antara tujuan syariat Islam adalah untuk memelihara atau melindungi harta benda, dengan maksud agar harta benda tetap suci, termasuk di dalamnya harta warisan agar tidak akan jatuh ke tangan orang-orang yang tidak berhak menerimanya. Di samping itu, kita tidak tahu siapa di antara kerabat kita yang lebih memberi manfaat kepada kita (Q.S. al-Nisā: 11). Itulah sebabnya mengapa masalah pembagian warisan diterangkan secara detil tentang siapa yang berhak beserta bagiannya masing-masing. ${ }^{2}$

Berdasarkan Surat al-Nisā ayat 7, 'illah kewarisan adalah kekerabatan.

Bagi laki-laki ada hak bagian dari harta peninggalan ibu-bapa dan kerabatnya, dan bagi wanita ada hak bagian (pula) dari harta peninggalan ibu-bapa dan kerabatnya, baik sedikit atau banyak menurut bahagian yang telah ditetapkan.

Hukum Islam mengatur nasab atau hubungan kekerabatan salah satu faktor penyebab seseorang dengan yang lainnya saling mewarisi. Kekerabatan sebagai sebab terjadinya pewarisan meliputi kekerabatan secara hakiki, yaitu karena hubungan nasab seperti kedua orang tua, anak, saudara, dan paman/bibi, atau keke-rabatan yang terjadi karena hubungan pernikahan maupun kekerabatan hukmi karena wala (pemerdekaan budak). ${ }^{3}$

Prinsip umum yang dipegang oleh Alquran dalam hal menetapkan aturan kewarisan adalah bahwa setiap kerabat mendapat warisan secara adil dan seimbang tanpa membedakan gender, anak kecil atau sudah besar, maupun perbedaan agama. ${ }^{4}$ Ibn Munzhir ketika menafsirkan penggalan ayat 11 surat al-Nisa bahwa "zhahir ayat ini menegaskan bahwa Allah swt mewajibkan agar kewarisan itu diberikan kepada seluruh anak, baik mukmin maupun kafir". Sementara, bagi umat Islam tentunya wajib menjalankan hukum dan ajaran juga aturan yang ditetapkan oleh agama Islam.

Hukum menyatakan bahwa ahli waris yang berbeda agama tidak mendapatkan harta warisan karena menyalahi syarat yang ditetapkan hadis Nabi SAW. Namun untuk merubah hal itu dengan cepat, tidak mungkin karena akan terjadi penolakan oleh umat Islam, jika orang yang berbeda agama itu dinyatakan akan menerima harta warisan sebagaimana ahli waris lain. ${ }^{5}$ Di sisi lain, rasa keadilan masyarakat juga menuntut ahli waris yang berbeda agama ini mendapat bagian dalam harta warisan dan menuntut ketentuan hukum itu dijadikan undang2018).

${ }^{2}$ Tinuk Dwi Cahyani, Hukum Waris Dalam Islam (Malang: Universitas Muhammadiyah Malang,

${ }^{3}$ Rosidi Jamil, "Hukum Waris Dan Wasiat (Sebuah Perbandingan Antara Pemikiran Hazairin Dan Munawwir Sjadzali),” Al-Ahwal: Jurnal Hukum Keluarga Islam 10, no. 1 (2017).

${ }^{4}$ Khisni, Hukum Waris Islam (Semarang: UNISSULA PRESS, 2017).

${ }^{5}$ Fadlih Rifenta, "Konsep Adil Dalam Hukum Waris Islam," FUADUNA : Jurnal Kajian Keagamaan Dan Kemasyarakatan 2, no. 1 (2019).

Al Qalam: Jurnal Ilmiah Keagamaan dan Kemasyarakatan Vol. 16, No. 2 Maret - April 2022 
undang. Akan tetapi jika itu dijadikan hukum, akan berbenturan dengan hukum yang lebih tinggi yaitu hukum Islam. ${ }^{6}$ Memperhatikan permalasalahan di atas timbul pertanyaan bagaimana hubungan kewarisan antar agama menurut hukum Islam.

\section{METODE PENELITIAN}

Jenis penelitian ini adalah penelitian kepustakaan (library research). Penelitian ini berbentuk deskriptif kualitatif dengan pendekatan filosofis dan konseptual. ${ }^{7}$ Penelitian yang merupakan penelitian pustaka ini bersumber bahan hukum primer dalam bentuk meneliti bukubuku, jurnal, serta hasil penelitian yang berkaitan dengan perbedaan agama sebagai penghalang dan status kewarisan serta upaya kompromisasinya. ${ }^{8}$ Data sekunder diperoleh dari buku-buku yang mendukung dengan permasalahan dalam penelitian ini, dan bahan hukum tersier berupa kamus bahasa dan ensiklopedi Islam. Metode analisis data yang digunakan dalam penelitian ini adalah metode analisis kualitatif. Data yang terkumpul dianalisis sesuai kebutuhan penelitian kemudian ditarik suatu kesimpulan. ${ }^{9}$

\section{HASIL DAN PEMBAHASAN}

\section{A. Perbedaan Agama Sebagai Penghalang Kewarisan}

Perbedaan agama, maksudnya adalah antara muwarits (orang meninggal yang diwarisi hartanya) dengan warits (orang yang masih hidup yang berhak mewarisi peninggalan karena adanya sebab-sebab kewarisan) masing-masing menganut agama yang berbeda, yaitu yang satu muslim dan yang lainnya non muslim, sedangkan perbedaan itu terjadi pada saat meninggalnya muwaris. Tidak termasuk perbedaan agama karena perbedaan faham atau sekte/mazhab dalam satu agama. ${ }^{10}$

Dalam fikih Islam, perbedaan agama menjadi salah satu penghalang kewarisan. Artinya, antara muwaris dan waris yang berbeda agama tidak dapat saling mewarisi. Hal ini didasarkan pada sebuah hadis yang diriwayatkan oleh al-Bukhari, Muslim, Abu Dawud, al-Turmudzi, dan Ibn Mājah dari Usāmah bin Zaid ra., bahwa Nabi saw. Bersabda:

${ }^{6}$ R Rohmawati, "Progresivitas Hukum Kewarisan Beda Agama Di Indonesia Berbasis Keadilan Dan Mașlahah," International Journal Ihya' 'Ulum al-Din 20, no. 2 (2018).

7 Poppy Yaniawati, "Penelitian Studi Kepustakaan," Penelitian Kepustakaan (Liberary Research), April (2020).

${ }^{8}$ Raco Jozef, Metode Penelitian Kualitatif: Jenis, Karakteristik Dan Keunggulannya (Jakarta: PT Gramedia Widiasarana Indonesia, 2010).

${ }^{9}$ Asep Kurniawan, Metodologi Penelitian Pendidikan (Bandung: Remaja Rosda Karya, 2018).

${ }^{10}$ Endang Sriani, "Fiqih Mawaris Kontemporer: Pembagian Waris Berkeadilan Gender," TAWAZUN : Journal of Sharia Economic Law 1, no. 2 (2018).

Al Qalam: Jurnal Ilmiah Keagamaan dan Kemasyarakatan Vol. 16, No. 2 Maret - April 2022 
Orang Islam tidak dapat mewarisi harta orang kafir dan orang kafir pun tidak dapat mewarisi harta orang Islam

Hadis ini secara tegas menyatakan bahwa adanya beda agama menjadi penghalang untuk saling mewarisi antara pewaris dengan ahli waris. Hukum menyatakan bahwa ahli waris yang berbeda agama tidak mendapatkan harta warisan karena menyalahi syarat yang ditetapkan hadis Nabi SAW. Muslim tidak dapat mewarisi harta yang ditinggalkan oleh ayah/ibu, anak, atau istri/suami yang non muslim (kafir); begitu pula sebaliknya si kafir tidak tidak dapat mewarisi harta peninggalan ayah/ibu, anak-anak, atau suami/isteri yang beragama Islam. Menurut al-Khaththabi dalam Ma'alim al-Sunan sebagaimana dikutip Shidqī Jamil 'Aththar ketika memberikan tahqiq terhadap kitab Sunan Abi Dawud, "keumuman hadis ini mengharuskan adanya penghalang saling mewarisi antara setiap muslim dengan orang kafir, baik orang kafir itu karena agama yang dianutnya sejak awal atau karena murtad yang mengharuskannya dibunuh. Oleh karena harta warisan si muslim tidak diberikan kepada orang kafir maka seharusnyalah harta orang kafir (juga) tidak diberikan kepada si muslim".

Hadis di atas secara eksplisit mengindikasikan bahwa perbedaan agama menjadi mani' (penghalang) pewarisan secara mutlak, walaupun sebab-sebab kewarisan terpenuhi, seperti adanya perkawinan yang sah atau kekerabatan hakiki, padahal menurut Alquran surah al-Nisā' ayat 11 yang menggunakan lafal aulad secara eksplisit menyatakan bahwa semua anak berhak mendapatkan warisan, baik mukmin maupun kafir.

Kedua nash ini seakan-akan menunjukkan kontradiksi (pertentangan/ ta'arudh); tetapi menurut pendapat para ulama, keumuman pengertian ayat 11 surah al-Nisā’ tersebut dikhususkan oleh hadis yang menetapkan bahwa perbedaan agama menjadi penghalang kewarisan. Jadi, dengan adanya hadis sahih dari Rasulullah saw. yang mengatakan bahwa muslim tidak bisa mewarisi harta peninggalan orang kafir, diketahui bahwa Allah swt. menghendaki (dengan kata aulad) itu adalah sebagian anak-anak, bukan sebagian yang lain (yang kafir, membunuh orang tuanya, dan lain-lain). Oleh sebab itu, "muslim tidak bisa mewarisi orang kafir, dan orang kafir tidak bisa mewarisi muslim sesuai lahir hadis". Pendapat ini adalah pendapat ulama yang berpegang pada kaidah bolehnya sunnah men-takhshish (mengkhususkan) keumuman ('am) Alquran atau penerapan kaidah bahwa" yang dikehendaki nash Alquran yang umum (aulad) itu adalah khusus sesama Islam, se-bagaimana ditegaskan oleh hadis Nabi saw. tersebut, dan kaidah dimaksud adalah al-'am yuradu bih al-khash".

\section{B. Macam-macam Perbedaan Agama dan Status Kewarisannya}

Perbedaan agama antara pewaris dan muwārits beserta status kewarisannya dapat dirinci sebagai berikut:

Al Qalam: Jurnal Ilmiah Keagamaan dan Kemasyarakatan Vol. 16, No. 2

Maret - April 2022 
a. Kewarisan orang kafir

Jumhur ulama dari kalangan sahabat, tabiin, dan para imam mazhab berpendapat bahwa dalam segala sebab kewarisan, muslim tidak dapat mewarisi harta peninggalan orang kafir. ${ }^{11}$ Oleh sebab itu, "suami muslim tidak dapat mewarisi harta peninggalan istrinya yang kitabiyyah, kerabat-kerabatnya yang muslim tidak dapat mewarisi harta anak, orang tua, saudara, atau paman yang kafir, dan begitu pula tuan (pemilik budak) yang muslim tidak dapat mewarisi harta budaknya yang kafir." Para ulama tersebut beralasan dengan hadis yang diriwayatkan oleh alBukhari, Muslim, Abū Dāwud, al-Turmudzi, dan Ibn Majah dari Usāmah bin Zaid di atas, dan hadis yang diriwayatkan oleh al-Bukhari dan Ibn Mājah dari Usāmah bin Zaid yang menerangkan bahwa ketika Abu Thalib wafat, ia meninggalkan empat orang anak, yakni 'Ali, Ja'far, 'Uqail, dan Thalib. 'Ali dan Ja'far, keduanya beragama Islam, sedangkan 'Uqail dan Thalib masih kafir. Rasulullah saw. membagikan harta pusaka Abu Thalib (yang meninggal dalam kekafiran) kepada 'Uqail dan Thalib, bukan kepada 'Ali dan Ja'far.

Adapun sebagian ulama berpendapat bahwa orang Islam dapat mewarisi harta peninggalan orang kafir, tapi tidak sebaliknya. Pendapat ini diriwayatkan dan diperpegangi oleh Mu'adz bin Jabal, Mu'awiyah bin Ab̄̄ Sufyān, Ishaq bin Rahawaih, Ibn al-Musayyab, dan alNakha'i serta kalangan fuqaha' Syi'ah Imamiyyah. ${ }^{12}$

Bertambahnya hak umat Islam itu adalah logis. Sebab, "di kala seorang pewaris sebelum ia masuk agama Islam sudah mempunyai hak mempusakai kerabatnya yang bukan Islam, maka setelah ia masuk Islam, niscaya haknya menjadi bertambah, tidak boleh makin dikurangi”. Oleh sebab itu orang Islam berhak mewarisi harta peninggalan orang non Islam. ${ }^{13}$

Kedua hadis yang dijadikan hujjah oleh kalangan yang memberikan hak mewarisi bagi orang Islam di atas orang kafir itu sangat interpertatif, mengundang berbagai penafsiran yang saling berbeda sesuai dengan persepsi masing-masing orang yang memberikan pemaknaan terhadap kedua hadis tersebut, sehingga tidak bisa dijadikan dasar untuk mengeliminasi ketetapan hadis sahih yang qath'i al-dalalah, yakni hadis yang dikemukakan oleh kelompok jumhur fuqahā. Apalagi hadis yang dijadikan hujjah oleh kelompok jumhur tersebut adalah sunnah qauliyyah dan juga sunnah fi'liyyah yang tidak memerlukan lagi interpretasi, sehingga pendapat pertama adalah pendapat yang terkuat. Oleh sebab itu, orang Islam tidak dapat mewarisi orang kafir.

\footnotetext{
${ }^{11}$ M. Bachtiar, "Hukum Waris Islam Dipandang Dari Perspektif Hukum Berkeadilan Gender," Jurnal Ilmu Hukum Riau 2, no. 02 (2012).

${ }^{12}$ Afidah Wahyuni, "Sistem Waris Dalam Perspektif Islam Dan Peraturan Perundang-Undangan Di Indonesia," SALAM: Jurnal Sosial Dan Budaya Syar-i 5, no. 2 (2018).

${ }^{13}$ Muhamad Isna Wahyudi, "Penegakan Keadilan Dalam Kewarisan Beda Agama: Kajian Lima Penetapan Dan Dua Putusan Pengadilan Agama Dalam Perkara Waris Beda Agama," Jurnal Yudisial 8, no. 3 (2015): 269-88.
}

Al Qalam: Jurnal Ilmiah Keagamaan dan Kemasyarakatan Vol. 16, No. 2

$$
\text { Maret - April } 2022
$$




\section{b. Kewarisan orang Islam}

Orang-orang Islam sepakat menetapkan bahwa orang kafir tidak dapat mewarisi harta peninggalan kerabatnya yang muslim, berdasarkan firman Allah swt. dalam surah al-Nisa' ayat 141:

Orang Islam tidak dapat mewarisi harta orang kafir dan orang kafir pun tidak dapat mewarisi harta orang Islam

Dalam masalah ini terjadi problem, apabila ternyata sesudah meninggalnya muwaris, orang kafir tersebut masuk Islam dan harta peninggalannya belum juga dibagikan. Jumhur ulama berpendapat bahwa, orang kafir yang kemudian masuk Islam sepeninggal muwarits, tetap terhalang mendapatkan bagian warisan. ${ }^{14}$ Sebab timbulnya hak mewarisi (mempusakai) adalah sejak meninggalnya muwarits, bukan pada saat kapan pembagian warisan dilaksanakan, padahal pada saat kematian orang yang mewariskan dia masih dalam keadaan kafir. Jadi, mereka dalam keadaan berlainan agama. Sedangkan Imam Ahmad dan fuqaha' Imamiyyah berpendapat bahwa "orang tidak terhalang mendapatkan warisan, sebab predikat beda agama sudah hilang sebelum pembagian warisan dan karena harta peninggalan itu belum menjadi milik ahli secara tetap sebelum dibagikan kepada orang yang berhak menerimanya". Dalam hal menentukan kewarisan terkait ahli waris yang berbeda agama,maka "ukuran dalam penetapan perbedaan agama adalah pada saat meninggal orang yang mewariskan". ${ }^{15}$

Memperhatikan alasan-alasan yang diajukan kedua pihak tersebut di atas, tampak bahwa alasan yang dikemukakan oleh jumhur ulama lebih kuat dan rasional, karena yang menjadi syarat mendapatkan hak mewarisi itu muncul pada saat muwarits meninggal dunia, bukan pada saat pembagian warisan. Kalau yang menjadi penyebab timbulnya hak kewarisan itu pada saat pembagian warisan, maka akan terjadi penyalahgunaan hak oleh pihak yang hendak mengambil keuntungan, yakni pada saat pembagian warisan dia masuk Islam dan setelah itu ia kembali murtad.

c. Kewarisan orang murtad

Orang murtad adalah orang yang semula beragama Islam, kemudian ia keluar atau meninggalkan agama Islam yang di-peluknya itu, baik dia memeluk agama lain atau tidak beragama sama sekali. Orang murtad yang seperti ini, termasuk dalam kategori beda agama. ${ }^{16}$

\footnotetext{
${ }^{14}$ Indah Sari, "Pengaturan Pembagian Hak Kewarisan Islam Berdasarkan Kompilasi Hukum Islam (KHI)," Jurnal Ilmiah Hukum Dirgantara 7, no. 2 (2017): 86-109.

${ }^{15}$ Junaidi dan M. Martindo Merta, "Perkawinan Beda Agama Dan Akibat Hukum Kewarisan Dalam Perspektif Hukum Islam," Prodising ISID 1, no. 1 (2020).

${ }^{16}$ Muhammad Muhibbuddin, "Pembaruan Hukum Waris Islam Di Indonesia,” Ahkam: Jurnal Hukum Islam 3, no. 2 (2015).
}

Al Qalam: Jurnal Ilmiah Keagamaan dan Kemasyarakatan Vol. 16, No. 2 Maret - April 2022 
Orang murtad tidak dapat mewarisi harta peninggalan kerabatnya yang muslim, berdasarkan ijmak ulama. Akan tetapi apabila dia meninggal atau dibunuh, apakah harta peninggalannya dapat diwarisi oleh kerabatnya yang muslim atau tidak. Dalam hal ini terjadi perbedaan pendapat di kalangan ulama. Jumhur ulama (Malikiyyah, Syafi'iyyah, dan pendapat yang sahih dalam mazhab Hanabilah) menyatakan bahwa orang Islam tidak dapat mewarisi orang murtad, karena tidak saling mewarisi antara muslim dan kafir, sedangkan riddah benar-benar telah keluar dari Islam. Ini berarti, dia menjadi kafir. ${ }^{17}$

Allah swt. berfirman dalam Alquran surah al-Baqarah ayat 217 yang berbunyi:

Barangsiapa yang murtad di antara kamu dari agamanya, lalu dia mati dalam kekafiran, maka mereka itulah yang sia-sia amalnya di dunia dan di akhirat

Harta fai adalah harta yang didapat dari orang-orang yang bukan beragama Islam, tanpa melalui peperangan dan kekerasan, tetapi secara damai dan penggunaan harta tersebut untuk kepentingan (kemaslahatan) umum. Misalanya, harta yang diperoleh dengan jalan menarik pajak, bea cukai, dan mengurusi orang murtad. sehingga hartanya menjadi fa' (ghanimah) bagi orangorang Islam. ${ }^{18}$ Menurut kalangan Hanafiyyah, "harta orang murtad yang diperoleh sesudah murtadnya tidak dapat diwarisi muslim dan menjadi hak baitul mal, sebagaimana pendapat jumhur. Tetapi harta yang diperoleh sebelum murtad menjadi warisan bagi kerabatnya yang muslim. Pendapat ini diriwayatkan dari Abū Bakr, 'Alī, dan Ibn Mas'ud”.

\section{Beda Agama dan Wasiat (Wasiat Wajibah)}

Perbedaan agama adalah salah satu penghalang kewarisan, karena keberadaannya memastikan ketiadaan hukum mendapatkan kewarisan itu, kendati telah nyata sebab-sebab kewarisan karena adanya kekerabatan (hubungan nasab atau perkawinan yang sah) antara orang muslim dengan orang kafir tersebut. Namun apakah dengan perbedaan agama itu sehingga tertutup sama sekali kesempatan seseorang mendapat bagian dari harta peninggalan muwarits, padahal ada peluang hokum yang memberikan kepada seseorang untuk mendapatkan bagian dari harta peninggalan itu, yaitu berupa wasiat. Hukum wasiat tidak mensyaratkan antara yang memberi dengan yang menerima wasiat itu harus seagama (sesama muslim), tapi kewajiban wasiat ditujukan kepada orang yang hendak meninggal dunia (mati) untuk kepentingan kedua orang tua dan para kerabat.

Di dalam surah al-Baqarah ayat 180, Allah swt. berfirman sebagai berikut:

\footnotetext{
${ }^{17}$ Rizki Isihlayungdianti dan Abdul Halim, "Non-Muslim Inheritance in Interfaith Marriages Kewarisan Non-Muslim dalam Perkawinan Beda Agama," Al-Mashlahah. (2012).

${ }^{18}$ Riyanta, "Kewarisan Beda Agama (Studi Pandangan Muaz Bin Jabal)," Asy-Syir'ah 46, no. 1
}

Al Qalam: Jurnal Ilmiah Keagamaan dan Kemasyarakatan Vol. 16, No. 2

$$
\text { Maret - April } 2022
$$


Diwajibkan atas kamu apabila seorang di antara kamu kedatangan (tanda-tanda) maut, jika ia mening-galkan harta yang banyak, berwasiat untuk ibu bapak dan karib kerabatnya secara ma `ruf, (ini adalah) ke-wajiban atas orang-orang yang bertakwa

Ayat di atas secara jelas menegaskan kepada kita tentang kewajiban berwasiat bagi orang yang akan meninggal dunia dan wasiat itu ditujukan kepada kedua orang tua dan karib kerabat secara umum, tanpa mempertimbangkan apakah kedua orang tua atau karib kerabat tersebut masih berhak menerima warisan atau sudah tidak berhak lagi, seperti karena berlainan agama.

Menurut jumhur fuqaha' dan fuqaha' Syi'ah Zaidiyyah, hukum berwasiat kepada kedua orang tua dan karib kerabat yang berhak menerima warisan, bagi orang yang akan meninggal dunia dan mempunyai harta peninggalan, tidak fardhu' 'ain, sebagaimana pendapat Ibn Hazm dan hukum berwasiat kepada kedua orang tua dan karib kerabat yang tidak berhak mempusakai adalah tidak wajib, seperti pendapat Abū Dāwud dan ulama salaf. Jumhur berargumen, bahwa ayat 180 surah al-Baqarah tentang kewajiban berwasiat tersebut telah di-nasakh keseluruhan hukumnya oleh ayat 11 surah al-Nisā dan hadis Nabi saw. yang diriwayatkan oleh Abū Dāwud dan alTurmudzi dari Abu Umamah al-Bahili yang berkata:

Aku mendengar Rasulullah saw. bersabda dalam khutbahnya pada tahun haji wadā': "Sesungguhnya Allah tabarak wa ta'ala telah memberikan kepada setiap pemilik hak akan halnya, maka tidak ada wasiat bagi orang yang mendapatkan warisan."

Oleh karena itu, kedua orang tua dan karib kerabat, baik yang berhak mewarisi maupun yang tidak, sudah tidak mempunyai hak untuk menerima wasiat. Sementara itu, "Abu Dawud dan ulama salaf, seperti Masruq, Thawus, Iyas, Qatadah, dan Ibn Jarir berpendapat bahwa wasiat itu hukumnya wajib dilaksanakan kepada kedua orang tua dan para kerabat yang karena satu atau beberapa sebab tidak dapat mempusakai”.

Dasar pemikiran Abū Dāwud dan kawan-kawan, adalah upaya mereka mengkompromikan ayat-ayat dan hadis yang secara literer seakan-akan kontradiktif (ta'arudh), yaitu antara ayat 180 surah al-Baqarah dengan ayat 11 surah al-Nisā' dan hadis yang menyatakan tidak ada wasiat bagi ahli waris. Ada dua cara yang dikemukakan oleh Abū Dawud untuk mempertemukan dua nash yang dianggap mengandung kontradiksi tersebut yaitu, pertama, ayat 180 surah al-Baqarah secara tekstual bersifat umum, akan tetapi yang dikehendaki adalah khusus (al-'am yuradu bih al-khash). Jadi secara tersurat dalam ayat tersebut dinyatakan bahwa kewajiban wasiat kepada kedua orang tua dan kerabat itu adalah bersifat umum, baik kedua orang tua dan para kerabat tersebut masih berhak mempusakai maupun sudah tidak berhak lagi. Tetapi secara tersirat, kewajiban berwasiat itu khusus tertuju bagi mereka yang sudah tidak berhak menerima pusaka (warisan). Kedua, bahwa memang terjadi naskh terhadap ayat 180 surah al-

Al Qalam: Jurnal Ilmiah Keagamaan dan Kemasyarakatan Vol. 16, No. 2

Maret - April 2022 
Baqarah oleh ayat-ayat dan hadis mawārits, tetapi naskh itu hanya pada sebagian hukumnya saja. Dengan demikian, kewajiban berwasiat kepada kedua orang tua dan kerabat-kerabat yang sudah tidak berhak mempusakai (mewarisi), misalnya karena berbeda agama, adanya tindak pembunuhan dan perbudakan, masih tetap berlaku.

Kendati pendapat Abu Dawud ini mendapat kritikan dan sanggahan dari kalangan jumhur, namun kesimpulan hukum yang ditariknya dari upaya mengkompromikan dua nash yang dianggap bertentangan adalah sikap yang sangat moderat dan lebih dekat kepada kebenaran dan rasa keadilan. Orang tua dan kerabat yang secara nasabiyyah (sebab pewarisan yang paling kuat) mestinya mendapatkan bagian warisan dari muwaris, akan tetapi karena adanya penghalang (māni' syar'i) seperti karena perbedaan agama, akibatnya mereka tidak berhak mendapatkan bagian warisan sebagaimana mestinya. Dalam kondisi demikian, orang tua atau karib kerabat tersebut bisa mendapatkan bagian dari harta peninggalan muwarits-nya dalam bentuk wasiat, baik wasiat itu sudah disebutkan oleh washi sebelum meninggalnya maupun wasiat wajibah. Dimaksudkan dengan wasiat wajibah adalah wasiat yang ditetapkan oleh penguasa atau hakim selaku aparat negara yang mempunyai kewenangan untuk memaksa atau memberikan surat keputusan wajib wasiat kepada orang tertentu dalam keadaan tertentu. Jadi orang tua dan kerabat yang berbeda agama dengan muwarits terhalang mendapatkan warisan, akan tetapi masih ada peluang hukum untuk men-dapatkan bagian peninggalan melalui jalur hukum wasiat atau wasiat wajibah.

\section{KESIMPULAN}

Dari uraian di atas, dapat disimpulkan bahwa antara nash Alquran, yang secara literal menganut prinsip umum persamaan hak mewarisi antara muslim dan kafir, dan hadis sahih yang bersifat khusus, yang menegaskan bahwa muslim tidak mewarisi orang kafir dan kafir tidak mewarisi orang muslim, harus diusahakan mengkompromikannya (al-jam' wa al-taufiq) sehingga kedua nash tersebut dapat dilaksanakan, baik melalui proses takhshīsh al-'am atau al-'am yuradu bih al-khash.

Implikasinya, bahwa prinsip hukum Alquran itu khusus membincangkan hukum kewarisan antara sesama muslim, bukan tentang hukum kewarisan antar agama. Perbedaan agama menjadi salah satu pengahalang (mani') pewarisan, oleh karena itu orang Islam tidak dapat mewarisi harta peninggalan orang kafir, begitu pula sebaliknya, orang kafir tidak bisa mewarisi harta peninggalan orang Islam. Akan tetapi, terhalangnya kedua orang tua dan kerabat mendapatkan warisan karena perbedaan agama, tidak menghalangi mereka memperoleh bagian harta peninggalan muwaris melalui jalur hukum wasiat atau wasiat wajibah.

Al Qalam: Jurnal Ilmiah Keagamaan dan Kemasyarakatan Vol. 16, No. 2

$$
\text { Maret - April } 2022
$$




\section{DAFTAR PUSTAKA}

Bachtiar, M. "Hukum Waris Islam Dipandang Dari Perspektif Hukum Berkeadilan Gender." Jurnal Ilmu Hukum Riau 2, no. 02 (2012).

Cahyani, Tinuk Dwi. Hukum Waris Dalam Islam. Malang: Universitas Muhammadiyah Malang, 2018.

Idzhar, Muhammad. "Hukum Kewarisan Islam (Studi Pelaksanaan Kewarisan Masyarakat Beda Budaya Kabupaten Kutai Kartanegara)." Journal of Chemical Information and Modeling 53, no. 9 (2013).

Isihlayungdianti, Rizki, dan Abdul Halim. "Non-Muslim Inheritance in Interfaith Marriages Kewarisan Non-Muslim dalam Perkawinan Beda Agama." Al-Mashlahah.

Jamil, Rosidi. "Hukum Waris Dan Wasiat (Sebuah Perbandingan Antara Pemikiran Hazairin Dan Munawwir Sjadzali)." Al-Ahwal: Jurnal Hukum Keluarga Islam 10, no. 1 (2017). https://doi.org/10.14421/ahwal.2017.10108.

Jozef, Raco. Metode Penelitian Kualitatif: Jenis, Karakteristik Dan Keunggulannya. Jakarta: PT Gramedia Widiasarana Indonesia, 2010.

Junaidi, dan M. Martindo Merta. "Perkawinan Beda Agama Dan Akibat Hukum Kewarisan Dalam Perspektif Hukum Islam." Prodising ISID 1, no. 1 (2020).

Khisni. Hukum Waris Islam. Semarang: UNISSULA PRESS, 2017.

Kurniawan, Asep. Metodologi Penelitian Pendidikan. Bandung: Remaja Rosda Karya, 2018.

Muhibbuddin, Muhammad. "Pembaruan Hukum Waris Islam Di Indonesia." Ahkam: Jurnal Hukum Islam 3, no. 2 (2015). https://doi.org/10.21274/ahkam.2015.3.2.187-198.

Rifenta, Fadlih. "Konsep Adil Dalam Hukum Waris Islam." FUADUNA : Jurnal Kajian $\begin{array}{lllllll}\text { Keagamaan Dan Kemasyarakatan 2, no. } & 1 & \text { (2019): } 23 .\end{array}$ https://doi.org/10.30983/fuaduna.v2i1.2024.

Riyanta. "Kewarisan Beda Agama (Studi Pandangan Muaz Bin Jabal)." Asy-Syir'ah 46, no. I (2012).

Rohmawati, R. "Progresivitas Hukum Kewarisan Beda Agama Di Indonesia Berbasis Keadilan Dan Mașlahah." International Journal Ihya' 'Ulum al-Din 20, no. 2 (2018). https://doi.org/10.21580/ihya.20.2.4047.

Sari, Indah. "Pengaturan Pembagian Hak Kewarisan Islam Berdasarkan Kompilasi Hukum Islam (KHI)." Jurnal Ilmiah Hukum Dirgantara 7, no. 2 (2017).

Sriani, Endang. "Fiqih Mawaris Kontemporer: Pembagian Waris Berkeadilan Gender." TAWAZUN: Journal of Sharia Economic Law 1, no. 2 (2018). https://doi.org/10.21043/tawazun.v1i2.4986.

Wahyudi, Muhamad Isna. "Penegakan Keadilan Dalam Kewarisan Beda Agama: Kajian Lima Penetapan Dan Dua Putusan Pengadilan Agama Dalam Perkara Waris Beda Agama." Jurnal Yudisial 8, no. 3 (2015).

Wahyuni, Afidah. "Sistem Waris Dalam Perspektif Islam Dan Peraturan Perundang-Undangan Di Indonesia." SALAM: Jurnal Sosial Dan Budaya Syar-i 5, no. 2 (2018). https://doi.org/10.15408/sjsbs.v5i2.9412.

Yaniawati, Poppy. "Penelitian Studi Kepustakaan." Penelitian Kepustakaan (Liberary Research), no. April (2020).

Al Qalam: Jurnal Ilmiah Keagamaan dan Kemasyarakatan Vol. 16, No. 2

Maret - April 2022 